\title{
Review of diagnostic procedures and control of some viral diseases causing abortion and infertility in small ruminants in Egypt
}

\author{
M.A. Mahmoud ${ }^{1}$, A.A. Ghazy ${ }^{1}\left(\right.$ and R.M. Shaapan ${ }^{2} \odot$ \\ ${ }^{1}$ Department of Parasitology and Animal Diseases, ${ }^{2}$ Department of zoonosis, Veterinary Research Division, National \\ Research Centre, Giza, Egypt.
}

\begin{tabular}{l} 
Article information \\
\hline Article history: \\
Received May 13, 2020 \\
Accepted July 14, 2020 \\
Available online June 24, 2021 \\
\hline Keywords: \\
Small ruminants \\
Abortion \\
Infertility \\
Diagnosis \\
Control \\
\hline
\end{tabular}

Correspondence:

R.M. Shaapan

rmshaapan2005@yahoo.com

\begin{abstract}
Sheep and goats represent an essential source of meat, milk and wool production. Infectious viral diseases of small ruminants hinder the expected benefits from these animals. The aim of the present review was to shed light on diagnostic procedures and monitoring of some important infectious viral diseases that affect small ruminants. Border disease (BDV) is caused by Pestiviruses. The affected herds are usually expressed high rates of infertility and production of underweighted-lambs. Affected lambs usually die within days after lambing. A commercial killed whole virus vaccine was produced for BDV. Louping ill (LI) is caused by the Louping ill virus, which is transmitted by Ixods ricinus ticks. The LI virus typically causes fever, anorexia and encephalomyelitis. Death could occur 1-3 days after the beginning of signs. The available Louping ill vaccine is composed of inactivated killed virus. Nairobi sheep disease (NSD) is a tick-born infectious disease caused by Rhipicephalus appendiculatus ticks, characterized clinically by fever, abortion hemorrhagic gastroenteritis and high mortality. Inactivated killed oil adjuvant virus vaccines are available for the control of Nairobi sheep disease. Akabane disease (AKAV) is a Culicoides borne viral disease belongs to orthobunyavirus that has a teratogenic effect on the fetus of cattle and small ruminants. A live attenuated virus vaccine and inactivated virus are commonly used. This review concluded that the modern diagnostic tools are urgently needed not only for diagnosis but also for monitoring viral disease control and control programs.
\end{abstract}

DOI: 10.33899/ijvs.2020.127114.1461, (O2021, College of Veterinary Medicine, University of Mosul.

This is an open access article under the CC BY 4.0 license (http://creativecommons.org/licenses/by/4.0/).

\section{Introduction}

The most common viral infections of sheep and goats in Africa are goats/sheep pox (SGPX), peste des petits ruminants (PPR), contagious ecthyma (CPD or ORF), Rift Valley fever (RVF), bluetongue (BT), Foot and mouth (FMD), Nairobi sheep (NSD) and Border (BD) diseases $(1,2)$. Other viral diseases are present outside Africa included Louping ill disease (LI), and Akabane disease (3). Some of these viral diseases have seasonal occurrence as Bluetongue disease, Rift valley disease, Peste des petites ruminants, Louping ill, Nairobi disease and Akabane disease. Others have worldwide distribution (e.g., FMD, PPR and SGPX) and others are restricted to particular regions (e.g., Border disease, Louping ill and Akabane disease). Some of sheep and goats viral diseases are transmitted directly from infected animals to the susceptible one (e.g. FMD, PPR, SGPX and CPD), others need an invertebrate host as Culicoides spp. (e.g. BT and Akabane disease), mosquitoes (e.g., RVF) or ticks (e.g., LI and NSD). Some of these viral diseases have zoonotic importance (e.g., RVF, Louping ill and CPD) and the others are not considered zoonotic. Many viral diseases such as FMD, the infectious Bovine Rhinotracheitis, and herpes viruses continually cause serious economic complications in the field (4-6). Most of the reported viral diseases of the small ruminants in Egypt lead 
to heavy losses in sheep and goats husbandry (4,7). In 1959, Border disease was described in sheep for the first time on the boundary between England and Wales. Nowadays, it is reported in several countries worldwide. The prevalence rates were varied between countries and from area to another within countries and the range are from 5\% to 50\% (8). The causative agent of the disease belongs to genus Pestiviruses, and is antigenically related to the BVD virus (9). The affected herds with Border disease usually show high rates of infertility, and production of underweighted-lambs $(10,11)$. Louping ill induces congenital deformities of the CNS in small ruminants that transmitted via ticks. Louping ill virus is a member of the genus Flavivirus (family Flaviviridae) (12). It can affect mainly sheep (13), cattle (14) and red grouse (15), but it also affects a wide range animal species including goats (16), pigs (17), dogs (18), horses (19), deer (20,21), alpacas (22) llamas (23) and mountain hares (24). The occurrence of LI is closely related to the prevalence of major vector ticks, Ixodes ricinus. The infection was described in different countries including Norway, Greece, Bulgaria and England (25). Louping ill is characterized by an initial febrile phase, which may be associated with depression and anorexia, and some animals tend to have nervous symptoms. The clinical signs in animals showing encephalomyelitis may be accompanied with muscle tremors that may progress in some cases to convulsions and/or coma (26). Death could occur 1-3 days after the beginning of signs. In some recovered animals, partial paralysis or residual torticollis may persist. All recovered animals are strongly protected for life $(27,28)$. When an outbreak of LI occurs in free area for the first time, the eradication is achieved by condemnation of infected animals and application of quarantines in combination with animal movement restrictions. Furthermore, Application of ticks control is recommended (29). In endemic areas, vaccination is the ideal methods for protection, or by avoiding exposure to environments where ticks are established. Maternal antibodies from naturally infected or vaccinated ewes usually protect newborn lambs for about 5 months of age (30). Nairobi sheep disease is predominant in sheep in Africa caused by Nairobi sheep disease virus (NSDV) or called Ganjam virus in Asia. Regardless of these two names, Ganjam virus and NSDV are nowadays considered the same virus, which belongs to the family Bunyaviridae and the genus Nairovirus. The distribution of NSD in East Africa is related to the presence of the vector; Rhipicephalus appendiculatus (31). Clinical signs begin with fever $41-42^{\circ} \mathrm{C}$ that lasts for 1 to 3 days after an incubation period of 4-5 days. Illness is marked by depression, dyspnea, anorexia, rotten dysentery that cause painful strain and mucopurulent or bloody nasal discharge. Death may occur during the febrile period or follow 2 days after decrease of the fever (32-34). Pregnant animals are usually abort. Nairobi sheep diseases must be suspected in the sheep or goats with severe hemorrhagic gastroenteritis and nasal discharge when it is present in or close to an enzootic area. The susceptibility of sheep is higher than goats. The existence of attached ticks increases the chance of the infection. The introduction of new animals into the affected area is an important epidemiological factor to be considered (35). In free areas, Nairobi sheep disease can be eliminated by controlling movement, quarantine and euthanasia of infected animals with tick control measures. Spraying or Dipping with acaricides is essential for goats and sheep to eliminate the vectors. Members of the Bunyaviridae viruses are liable to most common viral disinfectants like detergents, chlorhexidine, hypochlorite (bleach), alcohol, and phenols. Hygienic disposal from the dead animal by burring or incineration is recommended (36). Akabane disease is a Culicoides borne viral disease belongs to Orthobunyavirus that has a teratogenic effect on the fetus of cattle and small ruminant species. It was isolated in Japan for the first time in 1959 (37). Akabane virus was discovered in some countries of Africa, Southeast Asia, the Middle East, and Australia (38). When the following symptoms; Aborted, mummified fetuses, premature or even stillborn fetuses suffering from arthrogryposis and hydranencephaly, in association with high levels of morbidity 15 to $80 \%$ and high levels of mortality rates in newborns, Akabane disease infection is expected $(39,40)$. The best program for controlling of AKAV depends on vaccination of the liable animals before the season of the disease occurrence. A live attenuated virus vaccine has been applied in Japan, and inactivated virus vaccine that is appropriate for the emergency vaccination of pregnant animals was used in Australia, Japan and Korea (41). Vector control, such as breeding sites protected from flies, applying insect repellent and pesticide treatments may be effective (39).

Infectious viral diseases are difficult to be controlled because of the insufficient data of the epidemiology and different control strategies in the herds where the problems occur. Therefore, the aim of this review was to shed light on the diagnosis and control of some important viral diseases that affect dairy small ruminants.

\section{Diagnosis of Border Disease Clinical signs}

The affected herds are usually showed high rates of infertility, and production of underweighted-lambs with unusual hair and excessive pigmented fleece. Several skeletal deformities are present. Affected lambs usually die within days. But some lambs may survive and show a nervous sign which disappear gradually within 3-4 months $(11,42)$. Fetal death may occur at any stage of pregnancy, but it is more common in affected fetuses early in pregnancy. Small dead fetuses may be absorbed, or an abortion may pass unnoticed as the ewes remain well fed and show no sign of distress. As lambing approaches, large fetuses will be aborted, stillbirths and early and weaker lambs are born (43) (Figure 1). 

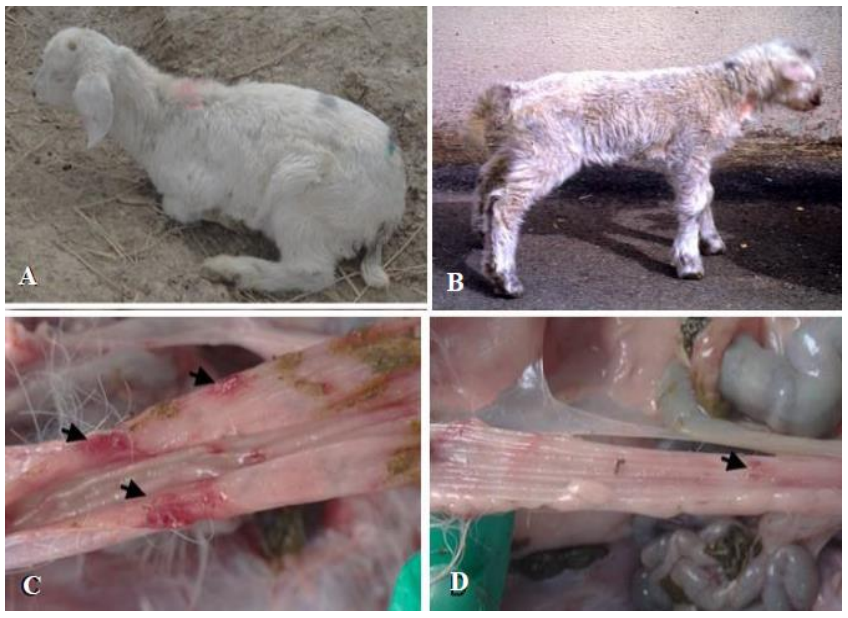

Figure 1: Clinical and pathological observations of Border Disease in goat: depression, growth retardation and rough hair-coat (A), emaciation and diarrhea (B.), hemorrhage and necrosis in large and small intestine (black arrows) (C and D) (32).

\section{Virus isolation}

Virus isolation is not applicable in the diagnosis of BDV except in the case of constantly infected sheep after congenital infection. Virus exposure by culture and antigen detection may be less reliable in lambs younger than two months old who acquired antibacterial antibodies. The acute infection is often subclinical, and fermi is temporary and difficult to notice. Isolation culture cells are semi-continuous cell lines derived from fetal pregnancy muscles (FLM) or choroid plexus cell culture (Table 1) (44).

\section{Polymerase chain reaction (PCR)}

Polymerase chain reaction have the ability to detect and identify the nucleic acid residues $(45,46)$. Tissues and blood from persistently infected (PI) sheep older than 3-5 months shows elevated levels of the virus, which can be easily detected by PCR. Because BVDV can attach sheep, so we must use diagnostic techniques that have wide diagnostic range of sensitivity for detecting all pestiviruses and also detect all strains of BDV and BVDV (Table 1) (8).

\section{Virus neutralization and ELISA}

ELISA is a more reliable test than isolation of the virus in the presence of antibodies. False negative results may occur in viraemic lambs less than 9 weeks old. ELISA is frequently of low sensitivity to detect acute BDV infections in the blood. Many types of commercial ELISA kits are now available for diagnosis of pestiviruses (8). ELISA and VNT are the frequently applied techniques. Acute cases of BDV could be diagnosed by testing paired serum samples and detection of the seroconversion. Due to the differences in antigenicity between BDV and BVDV, analyses needed for the detection of antibodies against BDV particularly by VNT, firstly based on a strain of BDV (Table 1$)(43,47)$.

Table 1: Test methods for diagnosis of border disease and its purposes (43)

\begin{tabular}{|c|c|c|c|c|c|}
\hline \multirow[b]{2}{*}{ Method } & \multicolumn{5}{|c|}{ Purpose } \\
\hline & $\begin{array}{l}\text { Population } \\
\text { freedom from } \\
\text { infection }\end{array}$ & $\begin{array}{c}\text { Individual animal } \\
\text { freedom from } \\
\text { infection prior to } \\
\text { movement }\end{array}$ & $\begin{array}{c}\text { Contribute to } \\
\text { eradication policies } \\
\text { Agent } \\
\text { identification }\end{array}$ & $\begin{array}{l}\text { Confirmation } \\
\text { of clinical } \\
\text { cases }\end{array}$ & $\begin{array}{l}\text { Prevalence } \\
\text { of infection/ } \\
\text { surveillance }\end{array}$ \\
\hline Virus isolation & + & ++ & ++ & +++ & - \\
\hline Antigen detection by ELISA & + & ++ & +++ & +++ & - \\
\hline NA detection by RT-PCR & +++ & +++ & +++ & +++ & +++ \\
\hline NA detection by ISH & - & - & - & + & - \\
\hline \multicolumn{6}{|l|}{ Detection of immune response } \\
\hline ELISA & ++ & ++ & ++ & + & ++ \\
\hline $\mathrm{VN}$ & +++ & +++ & ++ & +++ & +++ \\
\hline
\end{tabular}

Key: $+++=$ recommended method, validated for the purpose shown; $++=$ suitable method but may need further validation; + = may be used in some situations, but cost, reliability, or other factors limits its application; - = not appropriate for this purpose; $\mathrm{n} / \mathrm{a}=$ purpose not applicable. ELISA = enzyme-linked immunosorbent assay; IHC = immunohistochemistry; NA = nucleic acid; RT-PCR = reverse-transcription polymerase chain reaction; ISH = in-situ hybridization; VN = virus neutralization.

\section{Control of Border Disease}

Serological survey must be applied for all dams that have kids showing nervous signs. All of them must reveal appropriate high levels of antibodies to allow them to overcome the expected challenge with the virulent virus in the succeeding gestations (46). There is no BDV certified vaccine; however, a commercial complete killed virus vaccine has been produced. It is suitable for vaccination of the female prior breeding to avoid the transplacental infection (45). BVDV vaccines that are used in cows is not be recommended for sheep because the most common border disease viruses that are isolated from sheep differ from their 
antigens from the most common BVDV virus in cattle (47). To control BDV in a sheep herd, two conditions are necessary: Identifying constantly infected sheep (PI) and avoiding infecting pregnant sheep, especially in early pregnancy (42). Controlling of BDV in infected herds is difficult and depends on farmers' necessities regarding their farming methods. Before the next breeding season begins, all the positive animals to BD should be sent to the slaughter house. In highly infected endemic herds of high commercial value, antibody analysis for sheep of different ages will classify immune and vulnerable groups, and more blood tests can be used to classify the PI as negative and positive viruses. The positive animals must be culled (48).

\section{Border Disease in Egypt}

Few works have been done in Egypt on border disease. One study indicated positive results for BDV antibodies in $27.5,31.4,49.2,52.0$ and $52.5 \%$ in sheep, goats, cattle, buffalo and camels, respectively. In another study, sheep and goats fetuses were tested by using immunohistochemistry (IHC) and virus isolation (49). Two goats's kids showing classic border disease (BD) tested positive using immunohistochemistry (IHC), but when examined by four various monoclonal antibodies (MAbs) they showed negative results. By using PCR, one goat kid was positive for BVDV subtype $1 \mathrm{~b}$. The authors admitted that they isolated a pestivirus from goats for the first time in Egypt and perhaps the second finding worldwide of lamb presenting nervous signs accompanying with this disease (50).

\section{Diagnosis of Louping ill disease Clinical signs in sheep}

The incubation period of the disease ranges from six to eighteen days in sheep. Louping ill is characterized by an initial febrile phase, which may be associated with depression, anorexia and neurological symptoms. In endemic areas, many animals grow a mild or noncommunicable infection. In animals that show encephalitis, clinical signs may be accompanied by muscle tremors that in some cases developed to convulsions and/or coma (26). Observation of clinical symptoms together with the information of the existence of ticks and a history of the disease within the area, will give a strong idea of LIV infection. Signs include fine muscle tremor, nerve signs and ataxia (especially posterior limbs). Death can occur 1 to 3 days after signs begin. Per-acute deaths may also occur. In some recovered animals, partial paralysis or residual torticollis may persist. All recovered animals are strongly protected for life $(27,28)$ (Figure 2).

\section{Differential diagnosis}

The differential diagnosis in sheep and goats includes other causes of acute neurological disease. Toxemia, Scrapie, rabies, listeriosis, hypocalcemia, Coenurosis cerbralis, hypocuprosis and various poisons are among the considerations in sheep (51).

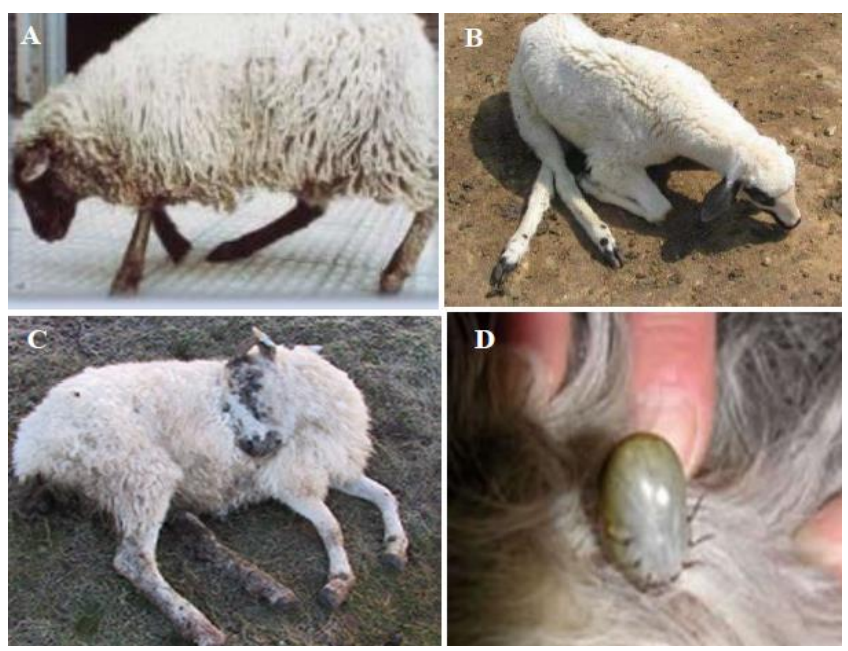

Figure 2: Clinical symptioms of Louping ill disease in sheep. Depression, (A), ataxia of the hind limbs (B), muscle tremors and neck rigidity $(\mathrm{C})$ and Ixods ricinus ticks (vector) embedded in the wool of infected sheep (D) (32).

\section{Post Mortem Lesions}

Louping ill attacks the CNS and leads to nonsuppurative meningitis and encephalomyelitis in the brain stem and cerebellum, as well as in the spinal cord (26).

\section{Laboratory diagnosis \\ Virus isolation}

The disease is caused by a member of the genus Flavivirus, family Flaviviridae named Louping ill virus (12). The virus could be isolated in lamb kidney cell lines, in addition to the embryonated eggs. It could also be cultivated by inoculation of suckling mice intra-cerebrally (28).

\section{Immunohistochemical staining}

This technique is helpful for the detection of LI viral antigens in the CNS (52).

\section{Reverse transcriptase polymerase chain reaction (RT- PCR) assay}

Nucleic acids of LI virus can be diagnosed by RT-PCR assay. This method was conducted to detect LIV in collected Ixodis ricinus ticks in Scotland endemic areas $(53,54)$. The assay showed similar sensitivity to virus identification and could be applied in cases where the virus cannot be isolated from tissue due to sample decomposition (55).

\section{Serological tests}

LI virus has hemagglutination inhibiting properties, so hemagglutination inhibition test could be helpful in the 
disease confirmation (56). Plaque inhibition neutralization test using LIV can also be applied to measure antiviral titers (27).

\section{Control of louping ill disease}

In free area eradication is achieved by condemnation of infected animals and application of quarantines in combination with animal movement restrictions. In endemic areas, controlling of the disease is achieved by vaccination and the use of insecticides (30). In any viral disease, there is no specific treatment. Good nursing and supportive treatment including is recommended. The most common disinfectants can affect the virus as it contains an envelope (57).

\section{Control of tick infestation}

Ticks control is recommended. It is essential to prevent the tick populations from being virally infected (29). Control of tick infestation is completed via treatment of sheep with acaricides, although there is an increasing evidence for the resistance of ticks to commonly used products. Land managing decreases the mat of plant material existing, which ticks need to stay alive during periods of low humidity (58).

\section{Public Health}

Humans can be infected the virus by tick bites or by direct contact with infected tissues or cultures. Transmission through wound contamination may occur. The aerosol infection has been reported. Drinking unpasteurized milk may lead to infection (28).

\section{Louping ill vaccines}

The available vaccine for animal use is manufactured commercially and composed of inactivated killed virus grown in tissue culture mixed with liquid paraffin/ montanide as an adjuvant. The appropriate age for vaccination is 6-12 months of age. A single dose is sufficient to induce defense for two years if injected under the skin $(26,59)$.

\section{Diagnosis of Nairobi sheep disease Clinical signs}

Clinical signs begin with fever $\left(41-42^{\circ} \mathrm{C}\right)$ and last for 13 days after an incubation period of 4-5 days. Fever may be biphasic. Leukopenia and viraemia usually correspond to the febrile stage of diseases. The disease is characterized by depression, loss of appetite, shortness of breath and moldy dysentery that causes painful strain and discolored nasal discharge. Death may occur during the fever stage, or two days after the fever is left behind (36). Pregnant animals frequently abort. Nairobi sheep diseases should be suspected in sheep or goats with severe gastroenteritis and nasal secretions when present in or near enzootic area. The susceptibility of sheep is higher than goats. The existence of attached ticks is helpful. The introduction of new animals into the affected area is an important epidemiological factor to be considered (35) (Figure 3).

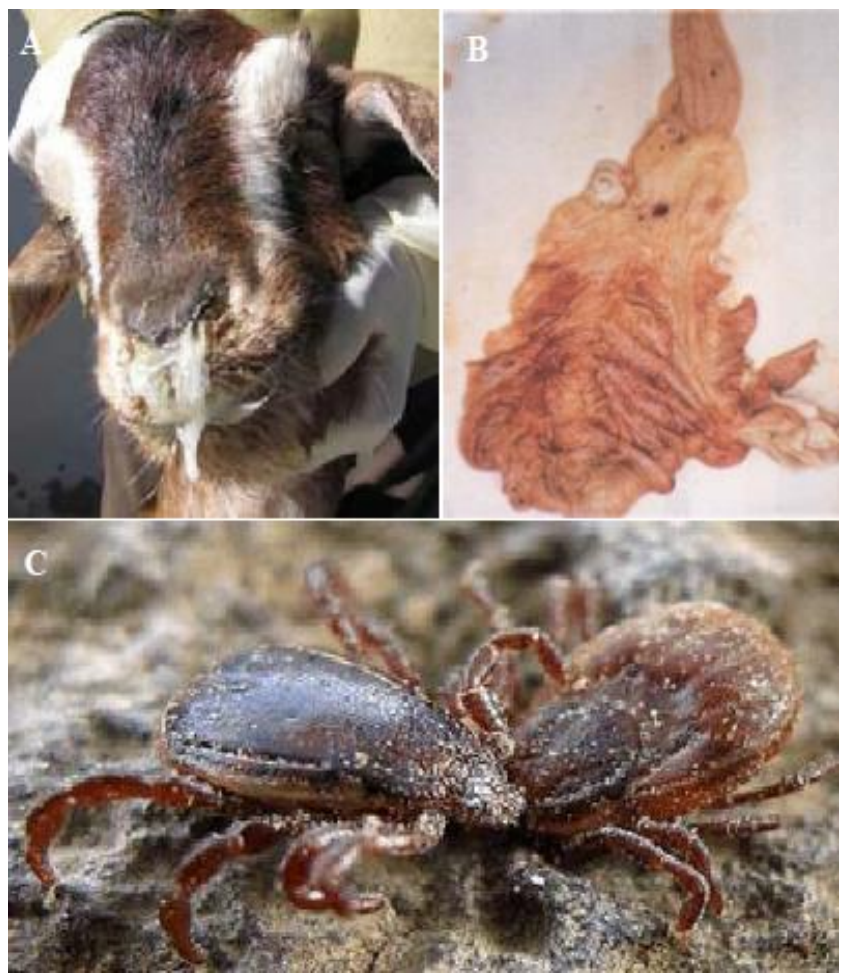

Figure 3: Nairobi sheep disease: clinical observations of mucopurulent, nasal discharge (A), acute haemorrhagic abomasitis (B) and the male and female Rhipicephalus appendiculatus ticks (transmissible vector) (C) (51).

\section{Post Mortem Lesions}

Both of the serous and mucosal surfaces of the visceral organs are hemorrhagic principally the abomasums, colon and female genital tract. Dried crust around nostril and conjunctivitis with is often noted (36). Enlarged and edematous lymph nodes are usually present. Hemorrhagic fetal skin and uterus are noticed. Ticks are possible to be existed in the body, mainly in the head and ear (32). The spleen is engorged with blood and severely enlarged (34).

\section{Laboratory Diagnosis}

For laboratory diagnosis, the sample includes blood or non-coagulated plasma, mesenteric lymph node, spleen, and serum safely to avoid aerosols. (32). No virus can be found in the blood after body temperature returns to normal. Two serum samples must be collected, apparently and recovered for serology. The sample for virus isolation should be kept cool as freezing reduces virus recovery (35).

\section{Isolation Nairobi sheep disease virus}

Nairobi sheep disease in Africa or a variant Ganjam virus in Asia can be isolated from whole blood obtained from 
tested animal at the early febrile stage. But in the case of the dead animal, the virus could be recovered from the mesenteric lymph nodes and spleen. Different cell lines, BSR cells or chiefly BHK-21-C13r, could be used for the isolation of the virus by following the examination of the cell culture using the indirect fluorescent test after staining or the direct fluorescent antibody test, provide the most dependable means of ascertaining NSDV. Using of fluoresceinconjugated antibody test help detection of the virus within 24-48 hours (34).

\section{Molecular detection}

RT-PCR is used for diagnosis in several laboratories and is said to detect the virus in an uncertain animal. Currently, marketable tests for the detection of viral antigens are not announced; however, antigens can be found in clinical specimens (for example, lymph nodes in the spleen and mesenteric) by diffusion of immunoglobulin gel, and ELISA has been identified in the literature. Cross reactions can occur with other Nero virus antigens $(42,60)$.

\section{Serological diagnosis}

Several serological tests have been used to identify antibodies to the NSDV / Ganjam virus. Double serum samples should be collected to detect increased titer. As reported by the World Organization for Animal Health, indirect immunofluorescence is the most appropriate assay, but ELISAs can also be used. Complementary fixation and indirect hematopoque were used, although it is rarely difficult to identify antibodies to neutralize the virus. Cross reactions with other Nair viruses, especially the Dugbe virus, can occur in serological tests $(42,60)$.

\section{Control of Nairobi sheep disease Prevention}

There is no available effective valid treatment for Nairobi sheep disease. Fluid therapy is suggested in diarrheic or dysenteric cases. Isolation and good nursing for the sick animal is recommended (34). In free zones, the disease can be eliminated by controlling movement, quarantine and euthanasia of infected animals with tick control. Dipping or spraying with acaricides is recommended for sheep and goat to eliminate tick vector. Members of the Bunyaviridae are easily affected by the most viral antiseptics such as hypochlorite, phenols, detergents, chlorhexidine, and alcohol. Hygienic disposal from the dead animal by burring or incineration is recommended (36). Vaccination of liable risk group such as native animal before the introduction to an endemic area is recommended.

\section{Vaccines for Nairobi sheep disease}

An attenuated live virus vaccine through inoculation in the mouse brain or killed inactivated virus vaccines combined with oil adjuvant are available. However, vaccination is not commonly practiced in endemic area because the animals tend to be immune and losses are sporadic (34). The two vaccines are preferable to be applied in two doses to elicit good protection. However, both vaccines are not commercially produced and accessibility is unclear (35).

\section{Diagnosis of Akabane disease Field diagnosis}

Akabane disease has a teratogenic effect on the fetus of cattle and small ruminants. Presence of the following symptoms; mummified fetuses, aborted or premature and even stillborn fetuses suffering from hydranencephaly and arthrogryposis in association with high levels of morbidity (15 to $80 \%$ ) and high levels of mortality rates in newborns leads to the suspicion of Akabane disease infection $(39,40)$ (Figure 4).

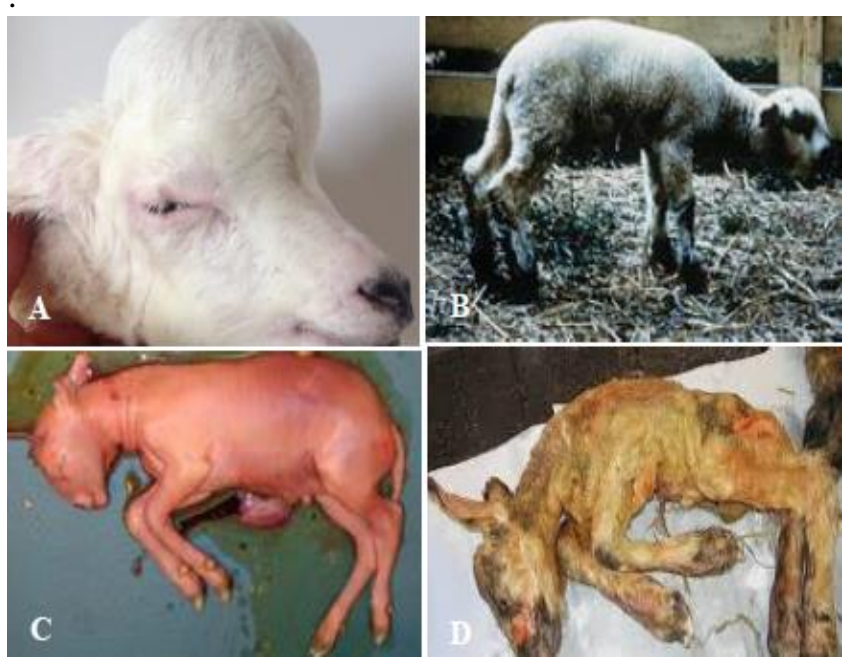

Figure 4: Akabane disease: clinical observations of hydranencephaly lamb (A), arthrogryposis (B), aborted, mummified fetus (C) and mummified fetus (D) (51).

\section{Laboratory diagnosis \\ Virus isolation and identification}

Akabane disease is a Culicoides borne viral disease belonging to Orthobunyavirus. Detection of the virus by virus isolation on BHK-21 (40) or polymerase chain reaction (PCR) may be considered if abortion occurred in the first third of pregnancy. By means of real-time PCR, it could be possible to detect residual RNA in suspected tissues of neonates and examinations of placental swabs might give positive results (61).

\section{Serological diagnosis}

Serological identification of the AKAV specific antibodies is most applicable and frequently used technique (62). Both the Virus neutralization test (VNT) and enzymelinked immunosorbent assay used for the identification of the specific antibodies against AKAV (63). Inadequate 
information established on virus detection and/or serology revealed the presence of AKAV in Africa $(64,65)$, and in China (66). Serological identification of the maternal immunity is of significance only in non-endemic areas. In these circumstances, positive maternal results raise the index of doubt, while a negative result will strongly reject the Akabane virus as the etiological agent.

\section{Control of Akabane disease}

The best program for combating AKAV depends on vaccination of the liable animals before the seasonal disease occurrences. A live attenuated virus vaccine has been applied in Japan, and inactivated virus vaccines that is appropriate for the emergency vaccination of pregnant animals was used in Australia, Japan and Korea (41 Adjustments to herd management can be applied, such as delaying mating or changing pregnancy periods from spring to autumn to avoid disease outbreaks if there is a warning that vector activity is approaching. Vector control measures, such as covering breeding sites, applying insect repellent and pesticide treatments, may be effective for a short time, but they are often ineffective in avoiding infection to the fetus for more than a few days but cannot control the disease forever (39).

\section{Conclusion}

Diagnosis of any viral disease depends on rapid identification of causative agents. Isolation of the causative virus from the field samples is the gold step for the diagnosis. Molecular technology provides the potential for more efficient and reliable methods for diagnosis of viral infection in case of the inability of viral isolation. The control program depends mainly on vaccination according to every virus, effective quarantine measures, hygiene and sanitation measures and finally vector control. BDV control depends on the identification of persistently infected (PI) sheep and the protection of the early pregnant sheep from the infection. Louping ill vaccine is inactivated killed virus whereas A live attenuated virus vaccine is available for Nairobi sheep disease. The best program for combating Akabane disease depends on a live attenuated virus vaccine in Japan, and inactivated virus vaccines in Australia, Japan and Korea.

\section{Acknowledgments}

Author wish to thank Knowledge his colleges in the both Department of Parasitology and Animal Diseases and Department of Zoonotic Diseases, NRC for supporting and providing facilities.

\section{Conflict of interest}

The authors of the current work declare that they have no conflicts of interest in this work.

\section{References}

1. Salem SA, Bazid AH, Abo El-Hassan DJ. Molecular and serological typing of foot-and-mouth disease virus serotypes currently circulating in Egypt. Iraqi $\mathbf{J}$ Vet Sci. 2021; Article in Press. DOI: 10.33899/ijvs.2020.127327.1495

2. Mahmoud MA, Khafagi MH. Detection, identification, and differentiation of sheep pox virus and goat pox virus from clinical cases in Giza Governorate, Egypt, Veterinary World 2016; 9(12):1445-1449. DOI: $10.14202 /$ vetworld.2016.1445-1449

3. Onono JO, Wieland B, Rushton J Constraints to cattle production in a semi-arid pastoral system in Kenya. Trop. Anim. Heal Prod. 2013; 45 : 1415-1422. DOI: $10.1007 / \mathrm{s} 11250-013-0379-2$

4. Mahmoud MA, Ghazy AA, Shaapan RM. Diagnosis and Control of Foot and Mouth Disease (FMD) in Dairy Small Ruminants; Sheep and Goats. International Journal of Dairy Science 2019; 14 (1): 45-52. DOI: 10.3923/ijds.2019.45.52

5. Al-Baroodi SY. Seroprevelance of schmallenberg virus infection as emerging disease in cattle in Iraq Iraqi J Vet Sci. 2021; Article in Press. DOI: $10.33899 /$ ijvs.2020.127071.1454

6. Ata EB, Zaghawa A, Ghazy AA, Elsify A, Shaapan RM. Equine Herpes Virus Type-1 Infection: Etiology, Epidemiology, Pathogenesis, Identification and Recent Diagnosis. Asian Journal of Epidemiology 2018; 11: 34-45. DOI: 10.3923/aje.2018.34.45

7. Mahmoud MA, Elbayoumy MK, Sedky D, Ahmed S, Serological investigation of some important RNA viruses affecting sheep and goats in Giza and Beni-Suef governorates in Egypt. Vet World 2017; 10 : 1161-1166. DOI: 10.14202/vetworld.2017.1161-1166

8. Yilmaz V, Yildirim Y, Coskun N. Molecular and serological investigation of border disease virus infection in sheep in the Kars District of Turkey. Acta Vet Brno. 2014; 83: 175-180. DOI: 10.2754/avb201483030175

9. Mishra N, Pitale SS, Rajukumar K, Prakash A, Behera SP, Nema RK, Dubey SC. Genetic variety of bovine viral diarrhea virus 1 strains isolated from sheep and goats in India. Acta Virol. 2012; 56: 209-215

10. Olde Riekerink RGM, Dominici A, Barkema HW, De Smit AJ. Seroprevalence of pestivirus in four species of alpine wild ungulates in the High Valley of Susa, Italy. Vet Microbiol. 2005; 108: 297-303. DOI: $10.1016 /$ j.vetmic.2005.04.014

11. Hassan SD. Prevalence of border disease virus in sheep and goats in Mosul, Iraq. Iraqi Journal of Veterinary Sciences. Iraqi J Vet Sci. 2021; 35(2): 257-262. DOI: 10.33899/ijvs.2020.126758.1372

12. Glazener WC, Cook RS, Trainer DO. A Serologic Study of Diseases in the Rio Grande Turkey. J Wildl. Manage 1967; 31: 34-39. DOI: $10.2307 / 3798357$

13. Smith CE, McMahon DA, O'Reilly KJ, Wilson AL. Robertson JM. The epidemiology of louping ill in Ayrshire: the first year of studies in sheep. J Hyg (Lond) 2009; 62: 53-68. DOI: 10.1017/S0022172400039772

14. Twomey, D. F., Cranwell, M. P., Reid, H. W. and Tan, J F. V., Louping ill on Dartmoor. Vet Rec. 2001; 149: 687. DOI: 10.1099/vir.0.062356$\underline{0}$

15. Williams $\mathrm{H}$, Thorburn $\mathrm{H}$, Ziffo GS. Isolation of louping ill from the red grouse. Nature, 1963; 200: 193-194. DOI: $10.1038 / 200193 \mathrm{a} 0$

16. Gray D, Webster K, Berry JE. Evidence of louping ill and tick-borne fever in goats. Vet Rec. 1988; 122: 66. DOI: 10.1136/vr.122.3.66

17. Bannatyne CC, Wilson RL, Reid HW, Buxton D, Pow I. Louping-ill virus infection of pigs. Vet Rec. 1980; 106 (1): 1-13. DOI: 10.1136/vr.106.1.13

18. MacKenzie CP, Lewis ND, Smith ST, Muir RW. Louping-ill in a working collie. Vet Rec. 1973; 92: 354-356. DOI: https://www.cabdirect.org/cabdirect/abstract/19732206489

19. Fletcher JM, Louping-ill in the horse. Vet Rec. 1937; 49: 17-18. [available at]

20. Reid HW, Barlow RM, Boyce JB. Isolation of louping ill virus from a roe deer (Capreolus capreolus). Vet Rec. 1976; 98: 116. DOI: $\underline{10.1136 / \text { vr.98.6.116 }}$ 
21. Reid HW, Barlow RM, Pow I. Isolation of louping-ill virus from red deer (Cervus elaphus). Vet Rec. 1978; 102: 463-464. DOI: 10.1136/vr.102.21.463

22. Cranwell MP, Josephson M, Willoughby K, Marriott L. Louping ill in an alpaca. Vet Rec. 2008; 162: 28. DOI: 10.1136/vr.162.1.28

23. Macaldowie C, Patterson IAP, Nettleton PF, Low H, Buxton D. Louping ill in llamas (Lama glama) in the Hebrides. Vet Rec. 2005; 156: 420-421. DOI: 10.1136/vr.156.13.420

24. Smith CE, Varma MG, McMahon D. Isolation of louping ill from small mammals in Ayrshire, Scotland. Nature, 1964b; 203: 992-993. DOI: $\underline{10.1038 / 203992 \mathrm{a} 0}$

25. Thakur SD, Panda AK. Rational use of antimicrobials in animal production: A prerequisite to stem the tide of antimicrobial resistance. Curr. Sci. 2017; 10: 1846-1857. DOI: 10.18520/cs/v113/i10/1846-1857

26. The center of food security and public health,. Louping Ill. Collage Vet Med. Lowa State Univ. J Sci. Technol. 2009b; 1-4. DOI: $10.1017 / \mathrm{s} 1368980009990735$

27. Balseiro A, Royo LJ, Martínez CP, de Mera IGF, Höfle Ú, Polledo L, Marreros N, Casais R, García Marín JF. Louping ILL in goats, Spain, 2011. Emerg. Infect. Dis. 2012; 18: 976-978. DOI: 10.3201/eid1806.120220

28. Jeffries CL, Mansfield KL, Phipps LP, Wakeley PR, Mearns R, Schock A, Bell S, Breed AC, Fooks AR, Johnson N. Louping ill virus : an endemic tick-borne disease of Great Britain 2014; 1005-1014. DOI: 10.1099/vir.0.062356-0

29. Inci A, Yildirim A, Duzlu O, Doganay M, Aksoy S. Tick-Borne Diseases in Turkey: A Review Based on One Health Perspective. PLoS Negl Trop Dis. 2016; 10: 1-12. DOI: 10.1371/journal.pntd.0005021

30. Gilbert L. Louping ill virus in the UK: a review of the hosts, transmission and ecological consequences of control. Exp Appl Acarol 2016; 68: 363-374. DOI: 10.1007/s10493-015-9952-x

31. Kusiluka L, Kambrage D. Disease of small Ruminant, a handbook. Common Disease of sheep and goat in sub-Saharan Africa. Scotland: Center for Tropical Veterinary Medicine 1996; VETAID

32. Constable PD, Hinchcli ,KW, Done SH, Grundberg W . Veterinary Medicine: A Textbook of the Diseases of Cattle, Horses, Sheep, Pigs, and Goats. 2017; 11th ed. Elsevier, UK, p: 1591. Hardcover ISBN: 9780702052460 [available at]

33. Kahn C, Line S. The Merck Veterinary Manual. Merck Vet Man. 2010; DOI: 10.1111/j.1751-0813.1962.tb04067.x

34. Shime A, Admassu B. Review on Nairobi Sheep Disease, World Journal of Agricultural Sciences 2016; 12 (2): 133-137, DOI: 10.5829/idosi.wjas.2016.12.2.23593

35. The center of food security 1nd public health, 2016. Nairobi Sheep Disease. Collage Vet Med. Lowa State Univ. J Sci. Technol. 1-4. DOI: 10.1186/s12889-019-6943-6

36. Baron MD, Holzer B, Nairobi sheep disease virus / Ganjam virus. Rev Sci Tech Off Int Epiz, 2015; 34(2): 411-417. DOI: 10.20506/rst.34.2.2367

37. Oya A, Okuno T, Ogata T, Kobayashii MT. Akabane, a new arbor virus isolated in Japan. Jpn. J Med. Sci. Biol. 1961; 14: 101-8. DOI: 10.7883/yoken1952.14.101.

38. Kirkland PD. Akabane virus infection The onset of viraemia with Akabane virus generally occurs. Rev. Sci. Tech. Off. Int. Epiz., 2015; 34, 403-410. DOI: $10.20506 /$ rst.34.2.2366

39. The center for food security and public health. Akabane Disease. Iowa State Univ. Collage Vet Med. 2009a; 1-4. http://www.oalib.com/references/4667812

40. Oluwayelu DO, Aiki-Raji CO, Umeh EC, Mustapha SO, Adebiyi AI. Serological Investigation of Akabane Virus Infection in Cattle and Sheep in Nigeria. Adv Virol. 2016; ID 2936082, 4 pp. DOI: 10.1155/2016/2936082

41. Kim YH, Kweon CH, Tark DS, Lim SI, Yang DK, Hyun BH, Song JY, Hur W, Park SC.. Development of inactivated trivalent vaccine for the teratogenic Aino, Akabane and Chuzan viruses. Biologicals 2011; 39: 152-157. DOI: 10.1016/j.biologicals.2011.02.004

42. Souf S. Recent advances in diagnostic testing for viral infections. Bioscience Horizons: The International Journal of Student Research, 2016; 9:1 hzw010, DOI: 10.1093/biohorizons/hzw010
43. Feknous N, Hanon J, Tignon M. Seroprevalence of border disease virus and other pestiviruses in sheep in Algeria and associated risk factors. BMC Vet Res 2018: 14: 339. DOI: 10.1186/s12917-018-1666-y

44. Li W, Mao L, Zhao Y, Sun Y, He K, Jiang J Detection of border disease virus (BDV) in goat herds suffering diarrhea in eastern China. Virol. J 2013; 10: 1. DOI: $10.1186 / 1743-422 X-10-80$

45. Braun U, Hilbe M, Janett F, Hässig M, Zanoni R, Frei S, Schweizer M. Transmission of border disease virus from a persistently infected calf to seronegative heifers in early pregnancy. BMC Vet Res. 2015; 11: 18. DOI: 10.1186/s12917-014-0275-7

46. Stalder H, Marti S, Flückiger F, Renevey N, Hofmann MA, Schweizer M. Complete Genome Sequences of Three Border Disease Virus Strains of the Same Subgenotype, BDSwiss, Isolated from Sheep, Cattle, and Pigs in Switzerland. Genome Announc2017; 5: 12-13. DOI: 10.1128/genomeA.01238-17

47. Torsson E, Berg M, Misinzo G, Herbe I, Kgotlele T, Päärni M, Roos N, Blomström AL, Ståhl K, Johansson WJ. Seroprevalence and risk factors for peste des petits ruminants and selected differential diagnosis in sheep and goats in Tanzania. Infect Ecol Epidemiol. 2017; 7(1):1368336. DOI: 10.1080/20008686.2017.1368336

48. Braun U, Janett F, Züblin S, von Büren M, Hilbe M, Zanoni R, Schweizer M. Insemination with border disease virus-infected semen results in seroconversion in cows but not persistent infection in fetuses. BMC Vet Res. 2018; 14: 1-8. DOI: 10.1186/s12917-018-1472-6

49. Zaghawa A. Prevalence of antibodies to bovine viral diarrhea virus and/or border disease virus in domestic ruminants. Zentralbl Vet Med. B. 1998; 45: 345-351. DOI: 10.1111/j.1439-0450.1998.tb00803.x

50. Abdel-Latif A O, Goyal S M, Chander Y, Abdel-Moneim AS, Tamam SM, Madbouly HM. Isolation and molecular characterization of a pestivirus from goats in egypt. Acta Veterinaria Hungarica 2013; 61 (2): 270-280. DOI: 10.1556/AVet.2013.007

51. Radostits OM, Gay CC, Hinchcliff K. Veterinary Medicine: A Textbook of the Diseases of Cattle, Sheep, Pigs, Goats and Horses, 2000; Ninth ed. London. [available at]

52. Burrell CJ, Howard CR, Murphy FA. Flaviviruses. Fenner White's Med. Virol. 2017; 493-518. DOI: 10.1016/B978-0-12-3751560.00036-9

53. Marriott L, Willoughby K, Chianini F, Dagleish MP, Scholes S, Robinson AC, Gould EA, Nettleton P.F. Detection of Louping ill virus in clinical specimens from mammals and birds using TaqMan RT-PCR. Journal of Virological Methods 2006; 137: 21-28. DOI: 10.1016/j.jviromet.2006.05.025

54. Johnson, N., Voller, K., Phipps, L.P., Mansfield, K., Fooks, A.R.,. Rapid molecular detection methods for arboviruses of livestock of importance to northern Europe. J Biomed. Biotechnol. 2011; 2012. DOI: $10.1155 / 2012 / 719402$

55. Patel P, Landt O, Kaiser M, Faye O, Koppe T, Lass U, Sall AA, Niedrig M. Development of one-step quantitative reverse transcription PCR for the rapid detection of flaviviruses. Virol. J 2013; 22: 10-58. DOI: 10.1186/1743-422X-10-58

56. Laurenson MK, Mckendrick IJ, Reid HW, Challenor R, Mathewson G.K. Prevalence, spatial distribution and the effect of control measures on louping-ill virus in the Forest of Bowland, Lancashire. Epidemiol. Infect. 2007; 135: 963-973. DOI: 10.1017/S0950268806007692

57. Lindqvist R, Upadhyay A, Överby A. Tick-Borne Flaviviruses and the Type I Interferon Response. Viruses 20181 10: 340. DOI: 10.3390/v10070340

58. Porter R, Norman RA, Gilbert L. A model to test how ticks and louping ill virus can be controlled by treating red grouse with acaricide. Med. Vet Entomol. 2013; 27: 237-246. DOI: 10.1111/j.13652915.2012.01047.x

59. Shaw B, Reid HW. Immune responses of sheep to louping-ill virus vaccine. Vet Rec 1981; 109: 529-531. https://europepmc.org/article/med/6280367

60. Shaapan R, Toaleb NI, Abdel-Rahman EH. Detection of Toxoplasma gondii-specific immunoglobulin ( $\mathrm{IgG})$ antibodies in meat juice of beef. Iraqi J Vet Sci. 2021; 35(2):319-24. DOI: $\underline{10.33899 / i j v s .2020 .126829 .1390}$ 
61. Lee JH, Seo HJ, Park JY, Kim SH, Cho YS, Kim YJ, Cho IS, Jeoung HY. Detection and differentiation of Schmallenberg, Akabane and Aino viruses by one-step multiplex reverse-transcriptase quantitative PCR assay. BMC Vet Res. 2015; 11: 1-5. DOI: 10.1186/s12917-015-05827

62. Oem JK, Yoon HJ, Kim HR, Roh IS, Lee KH, Lee OS, Bae YC. Genetic and pathogenic characterization of Akabane viruses isolated from cattle with encephalomyelitis in Korea. Vet Microbiol. 2012; 158: 259-266. DOI: 10.1016/j.vetmic.2012.02.017

63. Tsuda T, Yoshida K, Yanase T, Ohashi S, Yamakawa M. Competitive Enzyme-Linked Immunosorbent Assay for the Detection of the Antibodies Specific to Akabane Virus. J Vet. 2004; Diagnostic Investig. 16: 571-576. DOI: 10.1177/104063870401600613

64. Elhassan AM, Mansour MEA, Shamon AAA, El Hussein AM. A Serological Survey of Akabane Virus Infection in Cattle in Sudan. ISRN Vet Sci. 2014; 1-4. DOI: 10.1155/2014/123904

65. Mathew C, Klevar S, Elbers ARW, van der Poel WHM, Kirkland PD, Godfroid J, Mdegela RH, Mwamengele G, Stokstad M. Detection of serum neutralizing antibodies to Simbu sero-group viruses in cattle in Tanzania. BMC Vet Res. 2015; 11. DOI: 10.1186/s12917-015-0526-2

66. Wang J, Blasdell KR, Yin H, Walker PJ. A large-scale serological survey of Akabane virus infection in cattle, yak, sheep and goats in China. Vet Microbiol. 2017; 207: 7-12. DOI: 10.1016/j.vetmic.2017.05.014

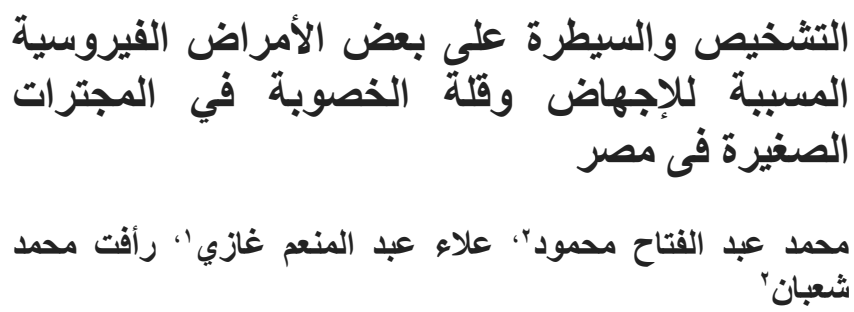

'قسم الطفيليات و أمر اض الحيوان، بَقم الأمر اض المشتركة، شعبه البحوث البيطرية، المركز القومي للبحوث، الجيزة، مصر الإن،

الخلاصة

تمثل الضأن والماعز مصدراً أساسياً لإنتاج اللحوم والألبان

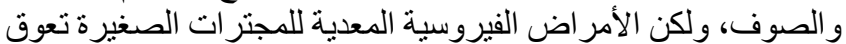

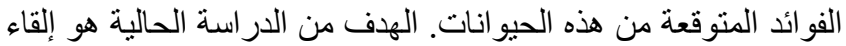

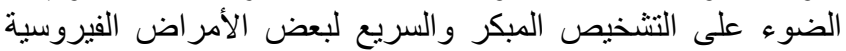

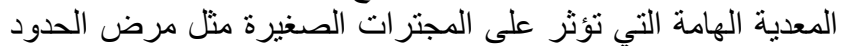

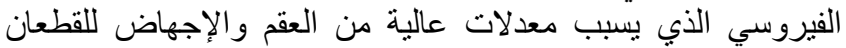

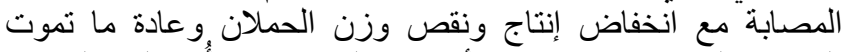

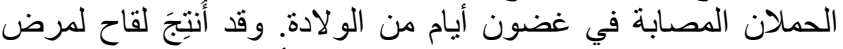

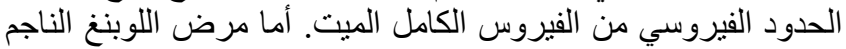

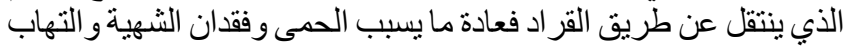

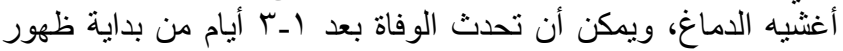

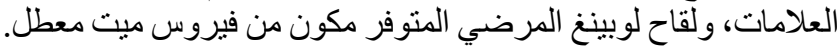

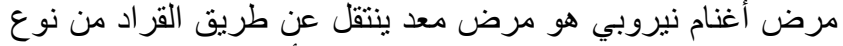
Rhipicephalus appendiculatus

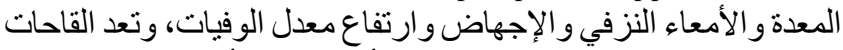

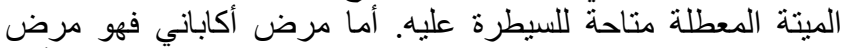

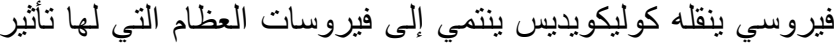

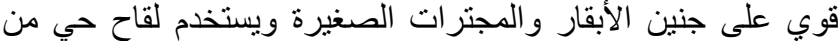

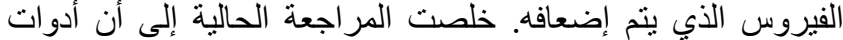

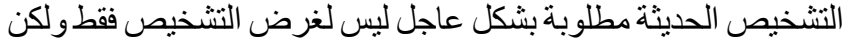

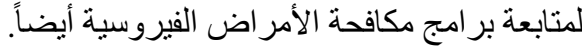

